\title{
GRUNDTVIG OG KINGOS SALMER
}

\section{Af Magnus Stevns $†$}

Enhver Digter er bestemt af Forgængere, som han ligner eller ikke ligner; absolut Originalitet er u-menneskelig, hvad hverken Poeten eller hans Værk kan blive, og saa særpræget Grundtvig end maa være, gør han i det Stykke ingen Undtagelse. Hans danske Salmedigtning begynder med Kingo til positivt Forbillede som Reaktion mod Evangelisk Christelig Psalmebog, og hvor mange ny Kilder der siden forenes i Sangværkets brede Strøm, fornægter denne aldrig helt sit Udspring.

Kingos Salmebog gemmer Barneaarenes Festsange fra Udby og Tyregod og har ene af den Grund sær Magt til at stemme Sindet, saa den mange Aar frem i Tiden vedbliver at „hviske til Hjertet, som Engle hilse fra Barne-Dage - “, og den er Festsang ogsaa fra den bevægede Tid paa Langeland. Men naar Grundvig bliver Præst, kan han ikke faa Lov at bruge den ved Kirketjenesten, da Ev. Chr. Psmb., hvor han kommer, er indført i Stedet for Kingos; selv fra Barndommens Kirke var Kingos Bog ved Grundtvigs Tiltræden af første Embede forsvundet til Fordel for den ny, der her - den Balleske Bog - var antaget af Familiehensyn mere end for sine Dyders Skyld, saa Far og Søn snart sukkede lige fortvivlet over den og i Smug, udenfor den officielle Gudstjeneste, trøstede Menigheden med den gamle.

I en Menneskealder kæmper Grundtvig mod den nye Bog for de gamle Salmer, før han tager sig Lov til at synge med sin Vartovmenighed, som han selv vil; og af den Kamp er hans Salmedigtning, der som næsten alt andet, han skriver, har pædagogisk Hensigt, i høj Grad præget. Ikke ved Siden af, men i Stedet for de ny skal de gamle Salmer, og frem for nogen Kingos, genindføres til Kirkebrug; dog ikke uden passende Forandring af den oprindelige Tekst, da baade "historisk Blik“ og „poetisk Samvittighed“ forbyder en simpel Krebsgang til 17. Aarh. Og saa tager Grundtvig fat paa at ændre.

I adskillige Digte bliver Omarbejdelsen saa gennemgribende, at man ligestraks vanskeligt forstaar, hvorfor „Konservator" ikke - som Ingemann og mange andre bad ham om - lader Kingo i Fred og selv skriver helt ny Digte i Stedet. Søger man Forklaring, maa vistnok 
ikke forbigaaes selve den Mindeværdi, Barneaarenes Salme har for Udby-Præstens Søn, og man maa nok heller ikke forbigaa en bevidst Benytten sig af, at den Digtning ogsaa for andre havde en lignende Tilsatsværdi. „Hvor de gamle endnu hulke, naar de høre Kingos HøitidsPsalmer", vil Anslagets Erindringsvægt spille stor Rolle for en velvillig Holdning fra den syngende Menigheds Side. Saa at sige alle Grundtvigs omdigtede Kingosalmer bevarer i første Omgang sammen med Strofeformen den oprindelige Indledning, og bortset fra, at Kingo virkelig har et fornemt Anslag, betyder det i Forbindelsen her, at man baade paa Ord og Tone faar begyndt helt „rigtigt“. „Det er jo den, jeg kan!" sagde Prinsessen. Sejlet fanger straks Bør, og Opmærksomheden afledes fra, at der dybere i Lasten faktisk er indskibet ny Ladning.

En anden Grund til, at Kingosalmen ikke helt opgives, selv hvor den næsten hules ud for sit eget Indhold og fyldes med noget andet, er den, at Grundtvig egentlig „digter" bedst, naar han foran sig paa Skrivepulten eller staaende klart i Erindringen har en bestemt fremmed Tekst at gaa med eller imod. Mere end afgjort Nyskaber er han tit den geniale Omdigter, der naar sit smukkeste Resultat, hvor han ligefrem begynder at afskrive en andens Digt, men alt som han kommer frem i Teksten retter denne ind efter sit eget Syn paa vedkommende Emne. Kingosalmen bruges som Igangsætter - undertiden endda for Digte, hvoraf den oprindelige Forfatter ganske forsvinder.

„Kingo har sin Styrke $\mathrm{i}$ en levende Opfattelse og høitidelig Fremstilling af Bibel-Historien, og, med eet Ord, i det simpelt Høitidelige, som bør være det Herskende i Bede-Huset for alle Folk, og som dog i vore Dage falder selv de største Skjalde vanskeligt at ramme; thi vel er det kun af private Grunde, at den i Kjøbstæd-Psalmebogen eftertragtede Høitidelighed blev lige saa uægte, som Halvfemtsernes Simpelhed, men at Digte-Konsten, selv hos dens ypperste Dyrkere, i det Mindste ikke endnu ret godt kan forene de lidt uhandelige Elementer, der hos Kingo af sig selv sammensmeltede, synes mig klart, - - hvoraf følger, at Kingo, som den Danske Kirkes $A s a p h$, fremdeles maa intonere og anføre Sjunge-Choret, naar der ei skal synges daarligere i det nittende end i det attende Aarhundrede -."

Naar Grundtvig udenom Evang. Chr. Psalmebog drejer ind i et Kingospor, som hans egen Digtning følger videre frem, er det Tilbagevenden til en Salme, der direkte øser af Biblen som litterær Stofkilde: historisk Beretning, Davidsalme, udvalgte Skriftafsnit, hvortil der kan knyttes kristelige Betragtninger. Kingosalmen har det Indhold, den mere kunstfærdige E. C. Psmb. mangler, og „hvem vil ikke heller have et frugtbart Viintræ med enkelte visne Grene, og endeel overflødige Blade, end en hartad tom Frugtkurv, skjøndt meget ordentlig flettet!" 
I Fremstillingen af dette „Indhold“ vil Grundtvig udenom E. C. Psmb.s Abstraktioner, hvor ,hele Synet forsvinder", tilbage til Kingosalmens konkrete Stillen for Øje og mener, at E. C. Psmb.s Omskrivning af Kingosalmer sammen med deres Original „burde staae i Rahbeks Læsebog, til et talende Eksempel paa Forskjellen imellem at udmale Billeder og udtvære Tanker“.

Ligesom Kingo vil Grundtvig gennem det karakteriserende Ord vise ind $\mathrm{i}$ og give Udtryk for noget vaesentligt i Sag og Person, der ikke træder frem men skjuler sig bag E. C. Psmb.s vage Betegnelser, som ved at sætte Gud Herren for din Frelser, det onde for den Onde, Mørkets frcekke Skarer for Luthers Djovle udvisker alle klare Linier ogsaa i Jesu Talebrug, saa Frelseren gaar tabt til den ene Side, mens Djævelen forsvinder til den anden.

Tilknytning til Kingosalmen bliver Tilbagevenden til en mere evangelisk og bestemt kristeligt præget Salme.

Den gode Salme skal som Kingos ,udtrykke det Christelige Fællesskab paa en vis almindelig Maade, der er omtrent alle kjær og klar, $i$ samme Grad, som de levende har tilegnet sig Troen og Haabet i vort Samfund!" Derved faar Menigheden, som Grundtvig ønskede det, selv Stemme, hvilket er noget ganske andet, end naar man behandler den „som en Flok Stærer og Papegøier, der ei selv have noget at udtale og udsjunge, men skal kun eftersnakke og efterkviddre hvad de BogLærde have optænkt, og ønske at høre af alle Munde!“

Salmen skal være Folke-Sang; men det kan Digtene fra E. C. Psmb. som subjektiv Kunstpoesi ikke blive, da det gælder om Kirkesalmerne ,at jo mere det Individuelle træder frem, desmere træder det Universelle tilbage, og des daarligere bliver altsaa Psalmen, som saadan, hvor mesterligt et Kvad for en snæver Kreds den end maatte være". Men blandt Kingos Digte findes derimod en lang Række, som opfylder Folke-Sangens Betingelser, og derfor skal Menigheden have dem tilbagegivet.

Grundtvigs ældste Forsøg paa at „forbedre“ Kingosalmer stammer fra 1810, da han drømte Reformatordrømme og i sin Søgen efter Midler, der kunde vække Folket og styrke den svage Kristendom, er standset op ved Tanken om at udgive en Samling kristelige, mest historiske Sange, der for ham er at ligne ved en rindende Bæk overfor den dogmatiske eller moralske Salme som stillestaaende Vande. „En Del skulde være selvgjorte, men den største Del borgede af Kingo, Luther og flere af de ældre kristelige Digtere, med de Forandringer, Tiden med Ret kan fordre." 
Udgivelsen kom aldrig istand, da Grundtvig snart fik nok at gøre med at samle sig selv; men blandt Forsøgene til den paatænkte Samling laa tilbage - først trykt efter hans Død - ogsaa nogle Kingodigte i ændret Skikkelse. De kan her forbigaaes som værdiløse. Kingos Stil lider overalt slem Overlast, og med Hensyn til Kingos Mening rykker Grundtvig kun bort fra den uden samtidig at rykke frem med sin egen, saa den faar nogen Karakter.

I de følgende Aar ændrer Grundtvig kun nu og da et Kingodigt; men 1831 faar han Lejlighed til at bearbejde en hel Række med det Formaal for Øje at gøre dem skikkede til Brug i Retning af, hvad han havde tænkt sig i 1810: Kingosalmen „med de Forandringer, Tiden med Ret kan fordre".

Det er ikke saa sikkert, Tiden vilde have fordret det samme i 1810 som nu, for Tiden betyder nærmest Grundtvig selv, og han lignede i 1832 ikke altformeget Kapellanen fra 1810, men den gamle Sangværksplan som saadan havde stadig samme Interesse og indenfor en bestemt Ramme realiseres den nu, da Student L. C. Hagen for at afhjælpe Savnet af „en liden Samling af de bedste gamle, især bibelhistoriske Psalmer og aandelige Viser" 1832 udsendte „Historiske Psalmer og Riim til Børne-Lærdom“. Heri findes en hel Række Digte under Kingos Navn, men alle i den Skikkelse, Grundtvig mente, de skulde have, saa han kan skrive til Ingemann: „Vel er jeg hverken Samler eller Udgiver deraf, men du vilde dog lige fuldt deri set samlet en Del gammelt og nyt af mine Forsøg og en Prøve paa, hvordan jeg mener, de Kingoske og Brorsonske Salmer burde ændres."

Grundtvig har ændret - mere eller mindre - alle Kingodigte, der blev optaget i Hagens Samling, og de to Trediedele af Digtene har lavere Strofetal, end de har hos Kingo, saa meget lavere, at en Fjerdedel af alle Strofer forsvinder af de forkortede Digte.

Der er ikke Tale om principiel Forkortning, fordi Digtene synes for lange. Snart mister et Digt paa 17 Strofer kun 2 af disse, mens et paa 10 Strofer mister 6, et paa 19 Strofer mister 10 , mens et paa 14 Strofer kun mister 1 etc. De fleste Udeladelser foretages af anden Grund og viser, ved at det er de samme Betragtninger og Forestillinger, der Gang paa Gang fjernes, at der er bestemte Ting, Grundtvig ikke vil have med.

Kingos historiske Salmer er oftest bygget op paa den Maade, at en Indledning søger at skabe den rigtige Holdning til Begivenheden, der skal berettes. Derefter følger den bibelske Fortælling, undertiden afbrudt af indskudte Reflektioner og Hjærtesuk, men ellers efterfulgt af det Hjærtesuk, der fremkaldes ved den bibelske Fortællings Anvendelse paa Sangeren selv : Saadan skete det! Hvordan er mit Forhold til Begivenheden! 
Det er navnlig i den Anvendelse, Grundtvig klipper, og igen særlig hvor Kingo gennem Jesu Fornedrelseshistorie, Maalestokken for Menneskets Syndeskyld, fremfører den voldsomste Selvanklage for med sin Synd direkte at være meddelagtig i Forhaanelse og Mishandling af Guds Søn - den Synd der ikke ophører med at antaste Mennesket, før Graven lukker sig om det, saa det bedste, Synderen kan gøre, egentlig er at sige Verden gode Nat og stride sig frem til Døden, der omsider løser ud af Besværet.

Men naar Vægten af Menneskets Skyld balancerer med Jesu Fornedrelse, maa der - naar der klippes i det første - for Balancens Skyld ogsaa klippes i det sidste, hvilket ikke altid er saa let, da det bliver Indgreb i den historiske Beretning, der just eftersynges. Men hvor et ikke altfor vigtigt Led derved forsvinder, fjerner Grundtvig dog ogsaa Strofer af rent historisk Indhold, eller han ændrer Fremstillingen deraf.

Efter Forkortningen slipper saa knap Halvdelen af Kingodigtene (her cit. efter P. A. Fengers Udg. 1827) med deres tiloversblevne Strofer kun lidet ændrede ind i Hagens Samling, i Resten er der af Gr. foretaget væsentlige $\nexists$ Endringer. Her anføres nogle faa blot til Angivelse af Arbejdets Retning:

Kingo (Fenger Nr. 15) :

„Søde Jesu, lær Du mig,

At jeg vandrer rettelig,

Og i Dine Fodspoer træder,

Ja udi Din Vei mig glæder!"
Gr. (Hagen Nr. 40) :

Tro igjen at tjene Dig

Dig og Dine Venner kjære

Herre til Gud Faders Ære!“

Og i samme Salme: Gør, Jesus, at jeg elsker Dig,

K. :

„Og forlindrer al min Nød

Med din Fødsel, Død og Smerte!

Tag dem aldrig fra mit Hjerte!“
Gr. :

„Som forsøder al min Nød, Med Dit Navn og med Din Naade: Daglig Trøst og evig Baade!“

I første Strofe gaar Grundtvig udenom Jesu Fodspor; i anden forsvinder K.s Aktivitet og Vejen gaar forbi Jesu Fornedrelse til Menneskets Frelse.

Daabens Vand renser ikke som hos K. fra Synd, der skiller Menneske og Gud, men til intimt Samfund af Mennesker og Gud, naar det hedder om den Kraft, Jesus ved sin Daab efterlod i Vandet:

K. (Fenger Nr. 30) :

„Ja alle andre Vand'

Ved Ordets Kraft maae tvette

Al Synd og Ondskabs Plette,

Som i os findes kan!"
Gr. (Hagen Nr. 21) :

„Ja, for af Vand med Ord

Et Sjæle-Bad at blande,

Som renser trindt om Lande

Til Gjæster ved Guds Bord!“ 
Ved Jesu Grav hedder det hos

$\begin{array}{ll}\text { K. (Fenger Nr. 63) : } & \text { Gr. (Fest-Psalmer Nr. 622) : } \\ \text { „Hvor han i Dødens Qvale } & \text { "Gik ned for os i Døden, } \\ \text { Uddrak Guds Vredes Skaale“ } & \text { Som Sol i Aften-Røden;“" }\end{array}$

Paa den Vis brydes Dødens Brod; men ogsaa Gravens Uhygge forsvinder hos Gr. snart fra Kingosalmen.

\author{
K. (Fenger Nr. 64) : \\ „Naar jeg mindes kun Din Grav, \\ Og betænker hvor Du laae \\ Udi Dødens mørke Vraae,"
}

\author{
Gr. (Hagen Nr. 34) : \\ Hvor med Engle-Vagt Du laae \\ Tændte Lys i mørke Vraa,“
}

1837 kom Sang-Vark til den Danske Kirke (citeres som SS I) samlet. og læmpet af N.F.S. Grundtvig. Her hvor Udvalget af Kingosalmer helt er Grundtvigs eget, medtages kun Halvdelen af de ændrede Digte fra Hagens Samling.

Gr. drejer udenom næsten alle Passionssalmerne og udelader forskellige Situationer fra Hagenteksterne, der stiller Mennesket i daarlig Belysning som skrøbeligt og lidet formaaende mod Synde-Lyst.

Til Gengæld er der i Sangværket medtaget Strofer, der først var udeladt hos Hagen, men nu optræder i ændret Skikkelse, saa man ligefrem kan se, hvorfor de først blev kasseret og hvordan de skal se ud for at faa Adgang til Grundtvigs eget Værk.

Iøvrigt fortsætter Gr. i Sangværket med at undvige Jesu Fornedrelses- og Lidelsesvej med dens stadige Erindren om menneskelig Skyld, og han finder først Sporet igen hinsides Golgata, hvor det er blevet Vej til Ophøjelse - ikke først og fremmest for Frelseren, men for Mennesket. Bevægelsen fra Kingo - evt. over Hagen - til Sangværket ser f. Eks. saaledes ud:

K. (Fenger Nr. 16): Hagen (Nr. 11): SS I Nr. 176:

Gud talte

„Til vore fordums Fædre, „Om Trøsteren i Nøden „Til vore gamle Fædre, om Jesu at fornedre,“ om Frelseren fra Døden,“ Om Støvets Kaar at

K. (Fenger Nr. 16): (Udeladt hos Hagen) SS I Nr. 176:

Jesus er

Jesus har faaet Almagten

„I Herlighed Guds Lige,

Han vil paa Døden træde,

O søde Jule-Glæde!

„Og os Han skænker

Livet,

Saa $v i$ med Jule-Glæde

Kan Døden undertræde !“ 
K. (Fenger Nr. 15) : $\quad$ Hagen (Nr. 40): $\quad$ SS I Nr. 318:

„Søde Jesu, lær Du mig, at jeg vandrer rettelig, Og i Dine Fodspoer „Tro igjen at tjene Dig, Dig og Dine Venner kjære, „Lad mig i Dit Fod-Spor træder, Ja udi Din Vei mig glæder!“

Herre til Guds Faders Indgaae til min Herres træde, Ære !“ Glæde !“

I sidste Samstilling ses det, hvorledes Fodsporet som første $\mathbb{E}$ dringsresultat forsvinder hos Hagen, men siden kommer igen - paa den anden Side Golgata.

Den stadige Fremgriben fra Frelserens til de frelstes Vej gælder ikke blot Bevægelsen udenom Golgata men ogsaa udenom Menneskets (Grundtvigs) Angst for Døden. Om Jesu Død hedder det hos K. (Fenger Nr. 46) og Hagen (Nr. 25), at den skal blive Sjælens Sang,

„Saa jeg drive kan og men i SS I Nr. 272

dræbe (Udhævelsen her) :

Døden, med Din Død paa

Læbe !“

„Saa jeg, med Din Død paa Læbe,

Min Døds-Angest kækt kan dræbe!"

Andetsteds griber Grundtvig fra Jesu Himmelfart frem til Genkomsten for at sikre sin egen Himmelfart.

K. (Fenger Nr. 70) og Hagen (Nr. 39) :

„I hvide-klædte Vidner, som

Stod hos, der til Sit Herredom

Min Jesus vild' opfare,

I minde mig, jeg op skal staae,"
SS I Nr. 317:

„Sneehvide Par af Engle-Kuld!

I vidne, at igjen til Muld

Min Frelser skal nedfare,

Da skal af Graven jeg opstaae,“

Angsten for den sidste Fjende faar Grundtvig til at bygge Sikringsværker, Kingo ikke har behov.

K. (Fenger Nr. 72) og Hagen (Nr. 47) :

„Om jeg og mod min sidste Stund

Fortaler mig - - -."

K. (Fenger Nr. 72) :

„Naar det er da mod Dødens Nat O, hjælp min Sjæl, hun faaer dig fat,“

K. (Fenger Nr. 64) og Hagen :

Tak, o Livsens Himmel-Helt

Som ei Døden kund' indspærre
SS I Nr. 387 :

„Lad ei os i vor sidste Stund Fortale os - - - -."

SS I Nr. 387 :

„Oplys i Dødens Nat vor Grav Og ræk vor Sjæl den Kiep og Stav,“

SS I Nr. 289 :

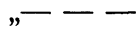

Tak, Du Livets Himmel-Helt

Som ei lod dit Støv indspærre

- - - -." (Udhævelsen her). 
K. : $\quad$ (Udeladt hos Hagen) Sangværk :

Ild og Vand opsluge mig!

Jeg døer i den Troe til Dig,

At jeg skal til Liv opstande

Udaf Dødens grumme Lande!“
„Selv i Fiendens Orme-Gaard Talt er mine Hoved-Haar, Og forklaret denne Tunge Evig skal din Priis udsjunge !“

Sangværket optager adskilligt flere Kingodigte end Hagens Samling; men Ændringsarbejdet gaar i de nyoptagne Tekster ad de vante Veje. Ved Jul hedder det f. Eks. i en historisk Salme henholdsvis hos K. (Fenger Nr. 11) og Gr. (SS I Nr. 174):

„Du ved Din Fødsel, Piin' og Død Skal knuse Satan, Synd og Nød

I Evighed nedtrykke!“
„Vi takke for det Naades-Tegn, Som under hver en Himmel-Egn

Gienføder Fred og Lykke!“

Mønten er den samme; men den ene Salmist slaar Plat, den anden Krone.

Eller ved Paaske:

K. (Fenger Nr. 65) :

„Hver rense sin Suurdeig af Hjerte Med Graad og Fortrydelses Smerte,

Al Ondskab fra Sjælen udfeie,

Og gamle vanartige Deige!"
Gr. (SS I Nr. 290) :

Kun kort er den tidlige Smerte, Og sødt er hvad Herren behager, Det kaldes usyrede Kager!“

Kingo naar ikke at faa renset det „gamle“ og „sure“ ud, før Grundtvig allerede har faaet sat „ny“ og „søde“ i Stedet.

Fyrrernes Salmesamlinger: Psalmeblade til Kirke-Bod fra 1843 og 1844 følger i Ændringsarbejdet Sangværkets Linier, hvilket ogsaa er Tilfældet med de bearbejdede Digte, Grundtvig i Fyrrerne og senere leverer som Bidrag til forskellige Præstevenners mere private Salmebogstillæg. Afstanden mellem Gud og Menneske, der efter Gr.' Mening i Kingosalmen er for stor, gøres mindre ved Understregning af intimere Slægtskab mellem Parterne: Sønnen af vor Fader bliver mere og mere Sønnen af vor Moder, og Frelsesværket, der hos Kingo oftest karakteriseres som Jesu Kamp mod Fjenden, bliver hos Grundtvig stadig mere Jesu Kamp for Mennesket.

Tendensen er den samme i det „Prøvehefte“, der 1845 blev udgivet af Kjøbenhavns geistlige Convents Psalme-Comitee; men her hvor Grundtvig kun optræder som medkommiteret og ikke uden videre kan ændre, som han vil, er der dog Tale om meget mindre vilkaarlig Behandling af Kingotekster end andre Steder. Komiteen opofrer, siger 
han, aldrig for hans Skyld det gamle. Prøveheftets Kingotekster giver derfor ikke noget rigtigt Maal for, hvorledes Grundtvig onsker, de skal se ud. Baade Grundtvigs Omarbejdelser og hans egne Digte er mindre grundtvigske i Prøveheftet end i Sangværket og i Festsalmerne.

Kingo og Grundtvig er i nogen Grad enige om, at den for Skjaldskab begavede Præst skal tjene de kristne til Gavn og Glæde i Kirke, Hjem og Skole, og at det overalt maa gælde, at Sagen er vigtigere end Smagen - selv om Kingo lægger mere Vægt paa Smagen end Grundtvig nogensinde gør. De skriver deres Salmer med det Maal for Øje at opvække og understøtte en ret kristelig Livsbetragtning hos Menigheden i videste Betydning. Her rækker de hinanden Haand udenom Evang. Chr. Psalmebog; men saa skilles de ogsaa og mødes først igen ved sidste Korsvej.

Hos Kingo føles Naaden urimeligst og nærmest for den, der dybest erkender en svimlende Afgrund mellem Guddommens rene Kærlighed og det elendige Menneskehjærte, „hvor Syndens Saar og Skrammer skær", saa intet mere er kendeligt af et Billede, der skulde ligne Gud. Et objektivt Maal for, hvor slet alt staar til i Hjærtet, faar Mennesket bedst ved at gøres bekendt med Prisen, der maatte betales for dets Frikøbelse af "Synd og Satans haarde Aag", hvorfor Kingo stadig paa ny fremlægger det gamle Regnskab, specificeret i direkte Henpegen paa Jesu Fornedrelse og Forhaanelse, der $\mathrm{i}$ intens Medleven følges til den bitre Ende, hvor uforskyldte Lidelsers bredfyldte Maal skummer over med Korsdødens Gru, og det beskuende Menneske modstandsløst rives ud i harmfuld Fordømmelse af det skete. Men i samme Øjeblik Hjærtet stempler Jødernes Skændselsdaad som den bundløse Uret og Ondskab, der ikke kan vinde Tilgivelse, forvandles det historiske Billede til et Spejl, hvori den betragtende med Gru ikke mere ser Jødeskaren, men sig selv :
„Mine Synder Dommen skrev, Og Dig hen til Døden rev; Hvor jeg seer Din Dom og Vunder, Seer jeg alt mit Segl derunder!“ (Fenger Nr. 59).

Staar først det klart, at alt er Prisen for "min Skyld og Brøde“, maa Hjærtet krympe sig under den voldsomste Selvanklage; men da det paa den anden Side gøres klart, at „min Skyld og Brøde" er betalt, maa Hjærtet samtidig fyldes med Fryd og Takskyld, saa Mennesket hengiver sig helt $\mathrm{i}$ den faste Beslutning, at „Nu bor ej Synden mere / Med Magt og Herredom / Udi mit Kjød regere, / Men daglig kastes om". 
Beslutningen lyder noget optimistisk for Synderen, der - under Erkendelse af Brøden - har reduceret sig selv til noget ganske afmægtigt og værdiløst: „En Orm er jeg og svag og fuld af Møie“, men bag Syndserkendelsen ligger den sikre Tillid til, at Guds Aand som stadig Kraftkilde er rede for enhver, der beder om Hjælp, og i den Tillid føres Kampen for daglig at kaste Synden om, en Kamp, hvori det tit nok med Bitterhed erfares, at Mennesket lokkes paa Afveje, forløber sig grumt og med hensynsløs Selvanklage og Bebrejdelse maa krybe tilbage i Bodsdragt og begynde forfra. „Ak Ak! desvær' man veed - " er i forskellig Formulering det tilbagevendende Hjærtesuk, naar det viser sig, at „det forbanned' Kjød“ igen var skrøbeligt, skønt Aanden var redebon. Det er langtfra nogen magelig Strid hver Dag at kaste Synden i Gulvet. Fjenden ejer jo en forfærdende Styrke - se blot til Syndeskyldens Umaadelighed og Korsdødens Jammer - han er naadeløs og grusom, men værst af alt, fordi ingen da kan vare sig for ham, hinterlistig, saa Mennesket Gang paa Gang med bitre Taarer ret „hjærtelig bejamrer, at Satan er saa snild.“

Vel er det nok frydefuldt hver Dag at modtage en Naade uden Maal, men den daglige Strid, der indskyder fjendtlige Magter mellem Gud og Menneske, gør alligevel, at det bliver godt at se hen til Døden, hvor Synderen endelig befries for en paatrængende Verden. Ja den kristelige Opdragelse bør endda med Iver gaa ud paa at skabe oprigtig Foragt for Verden og dens Forfængelighed, saa Mennesket kan lære at hade den og i redelig Kamp for en sød og salig Ende hugge sig Vej frem mod den legemlige Død, der hjælper Sjælen ud af Kroppens usle "Ormesæk“, saa den fri kan drage ad Himlen til.

Hvis ikke Salmerne ved stadig at holde Menigheden Jesu Kors og blodige Vunder for Øje kan befæste Synderen i Troen paa, at han engang skal indgaa til saligt Liv, og samtidig opelske en Kampvilje, der ukuet rejser sig af Fald og Nederlag i „Stride-Kirken“ for daglig at. hviste Verden fra sig indtil Forløsningstimen slaar, da bliver de kun matte og svage imod Syndens Anslag og Satans Snid og Træk, mener Kingo.

Men hos Grundtvig hedder der : „Naar vore Salmer ej udtrykke den levende Følelse af, at vi ere overgangne fra Døden til Livet, have fundet det evige Liv i Guds Kjærlighed og drukket af hans Saligheds Kalk, men udtrykke kun Mindet om Guds store og underlige Gjerninninger blandt Menneskenes Børn og Haab om Udløsning fra Forkrænkelighedens Baand, da er ogsaa de kun matte og svage i Sammenligning med, hvad Moses' den Guds Tjeners Sang, Davids og Asafs Salmer var for Israels Folk, som troede - “.

Mennesket har modtaget Frelsens store Naade, da Jesus jo har bragt Forsoning. Derfor henpeges hos Grundtvig ikke paa Synd og Død, men 
paa Sejren over Synd og Død, ikke paa Menneskets Trængsel i Dødens Rige, men paa Menneskehjærtets Længsel efter den opstandne, den Længsel der viser, at al Gud-Lighed ikke er slettet af Menneskehjærtet. Sejren vendes til Mennesket, som, hvor Kingo først sætter Segl under Dommen, først sætter Navn paa Listen til Opstandelsens Triumftog.

Grundtvig „vender Ryg til“ Synd og Satans Gerninger, hvor Kingo gør Front for at kaste Synden om. Kampen, der hos Grundtvig bliver tilbage, bestaar væsentlig $\mathrm{i}$ at bevare Troen paa, at "nu er her godt at være". I den Kamp maa Aanden som hos Kingo være stadig Bistand; men naar Kingo beder til Gud om at faa tilskikket Aandens Kraft fra det høje, taler Grundtvig til Aanden selv som den Guddom, der befinder sig i det lave.

Med Guds Aand og med Guds Ord er Guds Rige midt blandt Menneskene. Men saa maa ogsaa den legemlige Død, Kingo taler overlegne Haansord om, for Grundtvig blive den bitre grusomme Fjende, fordi den til sin Tid gør Skel imellem Støv og Aand: dummer Øret, der hørte Guds Ord; lammer Tungen, der glødede af Aandens Røst og bortvifter Varmen af det Hjærte, der favnede Jesus. Gravens Bred er for begge Salmister Bristningens Rand. Hos Kingo bliver det her, Syndens sidste Snærebaand skal løses. Hos Grundtvig er det her, Istaphaanden faar Tag i Jords og Himmels Hjærtebaand, som ikke maa briste.

Denne Forskel mellem Kingos og Grundtvigs Betragtning af Kristenlivets Kaar forklarer uden yderligere Kommentar væsentlige Afvigelser mellem Salmen, Kingo har skrevet og Kingosalmen, Grundtvig har omskrevet.

Der er ikke Spor Grund til at være uenig med Grundtvig, naar han skriver til Ingemann: „- det er en hel mislig Sag med alle Rettelser og Omarbejdelser af ældre Digte og Sange"; men i den sidste Ende kommer paa ejendommelig Vis alligevel noget værdifuldt ud af Misligheden. Det afhænger af Omdigtningens Grad og Maade.

Hvor et oprindeligt Digt beskæres eller rettes ind efter en andens Betragtning af Emnet, bliver det naturligvis den mest personligt prægede Del, der forsvinder af det gamle Digt. I de allerfleste af Grundtvigs Omarbejdelser er imidlertid Kingos Indledning bevaret, K.s Førstestrofe er som foran nævint den Part af Digtet, der pilles mindst ved, og det kan være farligt nok, fordi dens solide Bestik styrer hele Digtets Bevægelse. Det kommer til at slingre, naar man senere rykker ud fra den angivne Retning, saadan som det sker, naar Gr. snart her snart der med Eufemismer og anden poetiserende Omskrivning afsvækker oprindelige Udtryk. Digtets Helhedsbillede gaar itu, fordi det er urimeligt t.Ex først at faa mobiliseret hele Kingos Opbud af Kampkraft, naar der 
bagefter slet ingen Strid bliver af, eller højst kun en Skinfægtning mod den Fjende, der paa Forhaand er slaaet af Marken.

Helt karakterløst bliver det omdigtede Værk, hvor G. ikke nøjes med at lempe og dæmpe, men - irriteret til direkte Modstand - river en Kingostrofe ud hist og her og selv stikker ny af modsat Opfattelse ind i Hullerne. Omdigtning af den Art resulterer altid i en afgjort Forringelse af det oprindelige Digt, som paa den Vis ikke helt gøres til noget andet, men til hverken det ene eller det andet, hvad Ingemann allerede ved Fremkomsten af Hagens Samling 1832 godt saa og advarede imod: „Hvor nær beslægtet end din Aand er med Kingos, vil dog det stærkt ejendommelige hos eder begge ikke saaledes sammensmelte for mig, at jeg ikke snart maa høre den enes Røst og snart den andens, hvorved Salmen klinger mig ikke tostemmig, men som vexelvis afbrudt og fortsat af dig og den gamle med en kjendelig Stemmeforskel, som forstyrrer mig, blot derved, at jeg mærker det."

Noget anderledes forholder det sig, hvor saa store Dele af Kingosalmen skæres bort, at Grundtvigs Stemme faar væsentlig Overvægt, for Kraften fra den gamle Tekst føres her ikke helt sjældent over i den ny, saa vi efter Indledningen med Kingos energiske Anslag faar et Digt, der snart helt bliver Grundtvigs, men med samme trodsige eller frejdige Styren løs paa Maalet som det gamle Digt havde, skønt Maalet, der stræbes mod og Tanken, der udformes, ikke er Kingos.

Men helt fri for den dobbelte Stemmeklangs Ubehag er saadanne Digte endnu ikke. Selv om kun lidt overføres, bliver der, fordi netop den karakteristiske Intonation indstiller Forventningen paa Kingodigt, nok til, at Læseren hører noget skurre, hvor Stemmen skifter til grundtvigsk Fortsættelse. Først naar de enkelte Kingodigte glider tilbage som Reservefond, hvorfra der hentes snart et Billede, en bestemt Vending eller en speciel Kingoglose, som G. har Brug for, bringer Overtagelsen ikke nogen ubehagelig Andenstemme, men klinger tværtom som fortrolig gammelkendt Tone, der fryder Hjærtet. Her er jo ikke mere Tale om Afhængighed i den Forstand, at den senere Digter skriver saadan, fordi Forgængeren har skrevet saadan, men om et Slægtskab mellem de to, der gør, at den gamle Salmes Ord spontant melder sig som naturligt Udtryk for den senere Digters Tanke. Sangværket er gennemdrysset med saadanne Smaalaan, der tilsammenlagt vilde udgøre en ikke ringe Sum i Grundtvigs Skyldbrev til Kingo, og som bedre end de egentlige Ændringsarbejder viser, hvad Kingosalmen betød for ham. Nogle faa stemningsvækkende Ord fra den gamle Salme bliver Kernen, hvoraf nye Strofer i nye Forbindelser udvikler sig, eller der vokser ligefrem en ny hel Salme frem, saa ganske bestemt af den Grundtvigske Muldbund, at ingen, før der ligefrem peges paa Moder- 
planten, kan se, Grundtvigsalmen er en Aflægger hentet hos Kingo.

Til Eksempel kan nævnes Grundtvigs velkendte Digt: „I Nasaret, i trange Kaar,". Naar Kingo i sine historiske Salmer beretter om Jesu Fremstillelse $i$ Templet og om Jesu Tilbagekomst fra AEgypten, laaner Grundtvig herfra baade Materiale og Konstruktion - det sidste ikke blot til Strofeformen, der er en Udvidelse af Strofen fra sidstnæunte Kingodigt, men til hele Digtets Opbygning.

Kingo benævner Marie „Du bedste Jordens Qvinde!“

Grundtvig fortæller om, at i Nasaret, „Der bode Josef Tømmermand Med Jordens bedste Kvinde,".

Kingo lader Englene sige til Josef (Fenger Nr.25):

„Der er dog end en liden Plet,
Hvor Du kanst boe og bygge,
Udi det ringe Nazareth,
Der faaer Du Skjul og Skygge!“"

Den „liden Plet“ bliver hos Grundtvig „En lille kjøn og yndig Plet“, og om Jesu Barndomsliv i Kingos „ringe Nazareth" hedder det i Sangværket: „Saa voxed da i ringe Kaar" og „I Nasaret i trange Kaar". Efter Beskrivelsen af Nasaret som det trygge Tilflugtssted, fortrøster begge Digtere sig til at finde et saadant, saa det hedder hos hhv. Kingo og Grundtvig (SS III Nr. 100):

„Und mig et ringe Nazareth, En liden rolig Rede, Hvor jeg af Gud kan blive mæt, Og Jesum kun oplede!“
„Da har og Gud et Nasaret Til os ensteds paa Jorden, En lille kjøn og yndig Plet I Syden eller Norden, Hvor overalt vi ser Guds Spor - - - etc."

Ikke blot vigtige Gloser, Rim og Versrytme, men de respektive Digtes hele Opbygning over to Nasaretbilleder er saaledes fælles for Kingo og Grundtvig.

Men størst Betydning for Gr.s Salmedigtning har Kingo ejendommeligt nok haft med de Strofer eller Digte, der helt er Grundtvig imod. Vi har allerede set, hvorledes bestemte Forestillinger fra den gamle Salme fjernes eller ved mer og mindre heldig Manøvre vendes $\mathrm{i}$ anden Retning. Hvis nu ikke en ubehagelig Kingostrofe, samtidig med at den slettes af Teksten, ophører at irritere Gr., faar han ingen Fred, før den kommer med i ny Forbindelse, hvor den kan uskadeliggøres ved Omdigtning. Der er saaledes ikke blot endevendte Rester af Kingos Pinsedigt „Klaer op mit Hjerte, Sjæl og Sind“ i Grundtvigs Gravsalme „At sige Verden ret Farvel“, men disse Rester har haft betydelig Indflydelse paa Grundtvigdigtets hele Udformning. Der er et lignende For- 
hold mellem Kingos „Far Verden Farvel“ og Grundtvigs „Jeg kender et Land" (O Kristelighed), for det er jo ikke blot Kingos Strofe, forskellige Billeder og Gloser, Grundtvig bruger, alt det kunde være Laan af mere overfladisk Betydning; men hele den patetiske Drivkraft i Kingos Fornægtelse af Verdenslivet som Tant omkobles til Grundtvigs Bekendelse af Kærlighedsriget som sandt, saa Svinghjulet pludselig med samme Kraft som før drejer modsat Vej.

Først med saadanne Digte kunde der evt. holdes Mandjævning; men de betegner Yderfløje paa de to Salmeværk, fordi Digterne ved samme Udgangspunkt staar med Ryggen mod hinanden og ved Vejs Ende paa hver sin Grænse mellem Liv og Død. I Forbindelsen Grundtvigs Omdigtning af Kingosalmer naas her det absolutte: Kingos Emne skifter Fortegn, og af „Resten“ udelades Kingo helt, mens Grundtvig helt træder i Stedet.

Med den Stilling - med Ryggen mod hinanden - faar Kingo og Grundtvig overhovedet ikke noget fælles Billede i Synslinien. Anderledes hvor de staar vendt med Ansigtet mod hinanden; da ser begge de samme Foreteelser, men fra hver sin Side; og midt imellem dem staar Korset. Vi har allerede set, hvordan Grundtvig ændrer i forskellige Korsbilleder. Hvis Kingo nu koncentrerer et Digt om Fremstilling af den Korslidelse, Grundtvig ikke vil gengive, kan ogsaa det irritere saa voldsomt, at det aftvinger Grundtvig et helt nyt Digt som Modstykke, der paa det Punkt, hvor hans Salme mest adskiller sig fra Kingos, klart markerer Vejen til en ny Korsbetragtning - en Vej, der er højst interessant at følge, men som det ogsaa er nødvendigt at følge til Enden for at undgaa Mistydninger, Grundtvigsalmen i den Forbindelse tit nok var Genstand for.

Kingo-Salmerne om Jesu Korsvandring til Golgata, Christi Korsfæstelse, Pine og Død, der afslutter Kingos Passionsskildring, som Gr. ikke vil eftersynge, fordi han har ganske andre Ting at sige om Korset, modsynger Grundtvig simpelthen i Kingos Strofe og med Kingos Styrke.

K. (Fenger Nr. 60 og 61) :

„Kommer, I som vil ledsage Jesum til sit Retter-Sted!

Hvo der vil hans Kors paatage,

Kommer nu og følger med!

Bryder frem, I hule Sukke,

Solen haanes og bedækker Sig med Sørge-Dragt og Mørk' Mod Naturen Verden skrækker, Dagen er som Nattens Ørk;“
Gr. (Hagen Nr. 36) :

„Tag det sorte Kors fra Graven! Plant en Lilje, hvor det stod! Ved hvert Skridt i Dødning-Haven Blomster spire for vor Fod!

Frydesang for hule Sukke!

Himlen sortned', der Han blegned', Som os kjøbte med Sit Blod; Graven lyste, Mørket segned', Da forklaret Han opstod!“ 
Grundtvig er gaaet om paa den anden Side Korset, fra Langfredag til Paaskemorgen.

Den fulde Mening af Førstelinien i G.s Digt: Tag det sorte Kors fra Graven, kommer næppe frem uden Grundtvigs egen Forklaring: „Tag det sorte Kors fra Graven - — - at Kristi Kors igjen skal plantes paa sit rette Sted, som ikke er ved de Kristnes Grav, men ved deres Vugge, og at Kristi Kors igjen skal gives sin rette Farve, som ikke er Mørkets, Sorgens og Nederlagets den sorte, men Lysets, Glædens og Oprejsningens den hvide Farve, saa vi vil ligesaavel sige og synge: Slaae det hvide Kors for Vuggen! - - - hvor det kommer til os $\mathrm{i}$ Herrens Navn, og det veed vi jo alle er ved den hellige Daab, - hvor vi - betegnes med det hellige Kors baade paa vort Ansigt og paa vort Bryst til et Tegn paa, at vor Herre Jesu Kristi Kors skal hans sande Discipler altid have for Øje og kiærlig tilegne sig i deres Hjærte."

Kristi Kors bærer „Død til Herren, Liv til os". Den Side, der vender mod Langfredag, kan være nok saa sort; men den, der vender mod „os" er lys, og forveksles de to Sider, saa den ene tages for den anden, sker der det for Kristendommen fuldkomment opløsende, at det, der skulde være Liv, bringer Død: Paaskemorgen bliver Langfredag Aften. Det hedder, hvor Grundtvig (SS III Nr. 195) taler om Jesu Liv og Død:
„Om hans Liv og Død i Aanden
Korset vidner allerbedst,
Lever han, gjør det i Haanden
Sondag hver til Paaske-Fest;
Er han død, paa det som Stene
Slæber Simon fra Cyrene
Med et dybt Langfredags-Suk."

En følgende Strofe forklarer yderligere om førnævnte sorte Kors og slutter af med det ny Kors i et Billede, som allenfals ikke savner Klarhed, men hvor Digteren maaske noget for bogstavelig har grebet i sin egen Barm:
„Er han død, vi kun med Sukke
Plante Kors i Gravsted-Krog,
Lever han, ved hver en Vugge
Vajer Kors som Danebrog,
Flytter sig fra Kirkegaarden
Som vor Konges Ridder-Orden,
Straalekranset, til vort Bryst.“

Det hedder andetsteds (SS I Nr. 379) i Bøn til Aanden:

„Giv under Korsets hvide Flag

I Kongens Navn os Ridderslag

Og Rustning god derefter.“ 
Under højtvajende Kongeflag, Korsets Banner, Sejerstegnet fylkes Ridderordnen i lykkelig Sejrsfølelse: „Korsets hvide Sejers-Fane, / Som kan Helved byde Trods, / Hvilken herlig Løbebane / Aabner ikke den for os!" (SS III Nr.61). Langfredagskors er ikke Menneskenes:

„Vort Kors er uden Jammer, Vor Død er uden Brodd, - - -." (SS I Nr. 26).

Med den Betragtning af Korset og en næsten gennemført aktiv Gøren-sig-passiv i Striden, hvor Kingo intenst medlever „Herrens Storværk, Død og Pine“, kunde til forskellige Tider nok en og anden, som ikke var opmærksom paa en dybt bekymret Tone i mange af Grundtvigs Salmer, tage forkert Bestik og med Tilfredshed eller Modvilje finde, det var behagelig Kristendom, den gamle prækede. Men helt saadan stod Sagen nu ikke.

Naar Kingo af Korsets to Billeder først og fremmest hæfter sig ved det ene, Grundtvig først og fremmest ved det andet, maa man udtrykkeligt fastholde dette først. Der kommer ogsaa et nost.

Begribeligvis er ingen af Salmisterne i Tvivl om, hvordan Korset ser ud paa den anden Side, saa lidt som nogen af dem er i Tvivl om, at han jo maa kende dem begge, da Korset ellers til sin Tid - midt $\mathrm{i}$ Vejen der fører gennem Graven - uomgængeligt vil spærre Udgangen for den ene og Indgangen for den anden; og til Gravs vil Tiden med samme Ubønhørlighed føre baade Kingo og Grundtvig. De kommer til den fra hver sin Side, bærende hver sit Billede af Korset. Men hvor de mødes maa Billederne byttes om.

Begge Salmister søger stadig frem mod Forening med Guddommen gennem en Efterfølgelse der - om end svagt - faar Menneskets Vej til at ligne Guddommens. Men Guddommen selv, der er Gud og Menneske, tér sig for Kingo mest menneskelig (efterfølgelsesmulig) før Golgata, mest guddommelig (menneskefjern) efter Opstandelsen, mens det omvendte er Tilfældet hos Grundtvig, for hvem den opstandne er „Kjød i Himlen, Aand paa Jord“. Det vilde for Grundtvig være urimeligt at tro, Menneskets Kræfter var noget bevendt i Efterfølgelse af Guddommen „Kristus, som paa Korset døde“, før det kunde efterfølge Mennesket „Jesus som af Grav opstod“.

Kingo kommer til en Overbevisning, der lyder: Først naar jeg ved Døden ret kan sige Verden Farvel, $d a$ skal jeg være hos Gud som hjemme, mens Grundtvig naar til en anden, der lyder: Først naar Gud er hos mig som hjemme, $d a$ kan jeg sige Verden ret Farvel. Naar Kingo først har lært at kende Jesu Lidelses Kraft, skal han tilsidst lære at kende hans Opstandelses Samfund og Fællesskab. Men Grundtvig 
siger : „Herren ønsker, at alle hans Troende maa lære at kjende hans Opstandelses Kraft, før de føle sig kaldede til hans Lidelsers Samfund og Fællesskab - - Viljen til det altsammen den skal være og den er hos alle Troende fra Begyndelsen, men Magten og Kraften dertil, den er der ikke før Tiden kommer, og kræves ikke, før den findes. Derfor skal vi altid $i$ Herrens Navn trøste Menigheden med Jul til Paaske, med Herrens Fødselsglode til Erfaringen af hans Opstandelses Kraft, hvorved vi forberedes til hans Lidelsers Samfund og Follesskab, hvorigjennem Vejen gaar til den evige Herlighed."

Naar Kingo daglig kæmper mod „Synd og Død og alle Pile, som af Satan skydes kan", er der - hvad han meget villigt indrømmer - ikke nogen Udvikling til Stede, som gør Mennesket mere skikket til nogen afgørende Strid. Men for Grundtvig, hvor Naturlivet og Kristenlivet har samme Rytme og samme organiske Vækst, maa alting ventes i Naturens Orden. Ingen kan med Ret kræve Modenhed i Vaar. „Kristen“ betyder ikke noget, et Menneske er, men noget, det maaske gennem Kristenlivet kan modnes til at blive, og den Modnen maa der bies paa. Som Jesus først er Barn i Betlehem og derfra vokser sig til Mand, saadan maa ogsaa Mennesket først vokse og før Modningen kommer vogte nøje over bl. a. at dets Ord ikke bliver større, end at Styrken til Handling holder Trit med Ordene :

\author{
„Kun til spæde Børn i Aanden \\ Vi gjenfødes i vor Daab, \\ Og i os kun efterhaanden \\ Voxer Herlighedens Haab; \\ Kjøbe skal vi derfor Tiden, \\ Voxe først og kæmpe siden, \\ Herren selv, med Støvets Kaar, \\ Voxte ti og tyve Aar." (SS III Nr. 61). \\ Derfor Ingen Korset gribe, \\ Før med Herren han opstod! \\ Være maa Man først ilive, \\ Før Man føler Kraft og Mod.“ (SS I Nr. 312).
}

I en Fasteonsdagspræken afviser Grundtvig Beskyldningen for at præke „lystelig Kristendom“, hvor han taler om „Lidelseshistorien, - - thi siden sidst (det er siden forrige Faste, da Søren Kierkegaard endnu levede) er det med Verdens højeste Bifald udraabt paa vore Gader om os alle uden Undtagelse, at netop i denne Henseende forsømte vi saa skammeligt vor helligste Pligt - - Jeg har ingenlunde - - fordulgt, at vor Herre Jesus Kristus i sin Lidelse og Død skal 
staa for os baade som vor Frelser og som vort Mønster, - - Det er Herrens egen Lærdom, at vi skal tage os vel i Agt for at ville ligne ham mere udvortes, end vi ligne ham indvortes, eller at ville tilsyneladende følge ham - paa hans tornefulde Vej til Korset, end vi i vort Hjærte har Kraft og uforkrænkelig Kiærlighed til. — - Dengang nemlig Simon Peder sagde: Herre! hvor gaar du hen? da svarede Herren : hvor jeg gaar hen kan du ikke følge mig $n u$, men herefter skal du følge mig - - ".

Som Udtryk for Grundtvigs i dyb Alvor tilkæmpede Erkendelse og Anerkendelse af Livets Vilkaar, gengives nogle Strofer af et didaktisk Salmedigt fra Aarene 1846-50 (SS III Nr. 209):

1) „Har vi toppet, maa vi dale, Det er Loven under Sol, Hører det, I høje Sale ! Høre det hver Kongestol! Som for Haanden, Saa i Aanden:

Op og ned er Verdens Løb.

3) Ned ad Bakke, let at komme, Om end tungt at tænke paa, Maa vi, før vort Løb er omme, Før vort rette Maal vi naa, Skjønt til visse

Over Isse,

Over Bjærg og Sky det staar.
2) Naar med Herren Glans og Ere Du af Gud paa Bjærget faar, Siig kun : her er godt at være!

Du dog ej dig selv forstaar, Om tillige

Du vil sige, Det er bedst, vi bliver her.

4) Lejret mellem Fjendehære, Angest i Getsemane, Siig kun : her er slemt at være, Hvor kun Mørke er at se!

Da du nemmer

$\mathrm{Og}$ istemmer :

Det er bedst, vi gaar her fra!
5) Med det Ord gik Frelsermanden Gjennem Dødens Skyggedal,

- - -

9) Aften først, derefter Morgen, Saa den gamle Regning lød, Evig Fryd kun efter Sorgen, Evigt Liv kun efter Død, Vi maa krybe, Før vi flyve, Ned og op gaa Jesu Spor.“
6) Har med ham din Sjæl sig bøjet, Skjult sig selv med Flid i Muld, $\mathrm{Da}$ du vorder ret ophøjet, Kronet med det ægte Guld ; Engle kvæde :

Her er Glæde, Ven med Herren! gak her ind!

Grundtvig ved god Besked om Loven under Sol og dens Forhold til Maalet over Sky :

$$
\text { Op og ned er Verdens Løb - Ned og op gaar Jesu Spor. }
$$


Naar Digtene om Kristenmenneskets Færd ned ad Bakke ikke klinger igennem med samme Vælde som Digtene om Sejrens palmestrøede Vej, er det ikke blot, fordi Grundtvigsalmen gjorde sig til første Opgave at vække Menigheden til Liv i Stedet for til Død, men ogsaa fordi Lovsangen over Livet bæres af Menighedens mange Stemmer, hvorimod Vandring mod Døden - „ene med Herren i Aanden“ - afføder en Lønkammersang, der klinger mere dæmpet, men i Tonens Renhed og Dybde overgaar baade Sangværkets Festhymner og Kingos Basunsalmer.

Men i Grundtvigs Salme er vi da ret beset paa Kvindens Vej, der udgaar med Opstandelsesglæden fra det hvide Kors for siden gennem Lidelse og Hen-Givelse at føres nedad mod det sorte til Gravens Viadukt. Det lyder underligt, for det gør den Slags Hemmeligheder.

Den Efterfølgelse, Grundtvig digter om, betyder ikke Efterfølgelse blot med Henblik paa Lidelse - og navnlig ikke først Lidelse - men paa Jesu hele Liv: Fra Barndommens Spiren i Vaar til Manddommens Blomstring med Sommer og endelig Hjærternes Skælven mod Høst. Sommerens Grøde og Kræfternes Spil er Aandens Tid med dens mandlige Føren sig frem - og i Grundtvigs Salmer er det Pinse, før det bliver Paaske. Men Høstens Dage under gylden Tynge er Hjortets Tid med Kvindens selvudslettende Hen-Givelse. Det gælder for Frelseren som for den frelste, „saa vor Frelser efter at have virket som Aanden og Manden maatte lide og dø som Hjærtet og Kvinden i Guds-Mennesket; ligesom vi, naar vi har lært at kende hans Opstandelses Kraft, tilsidst skal lære at kende hans Lidelsers Samfund og Fællesskab“.

Vi er hermed ude af direkte Forbindelse mellem Kingos Salme og Grundtvigs - og alligevel maaske ikke helt.

At Kingo mere end nogen anden Salmist fik Betydning for Grundtvig, er Gr. selv den første til at indrømme; men naar man samtidig erindrer, at Gr. næsten altid forholder sig mere reaktivt end imitativt over for sine Forgængere, sker det Gang paa Gang, at man standser op i Grundtvigs Salmer og paa Spørgsmaalet „hvorfor skriver han netop saadan“, svarer sig selv: „fordi Kingo skrev noget ganske andet“.

Kildeangivelserne $i$ ovenstaaende Afhandling er tilføjet af Red. 